\title{
HAZARD IDENTIFICATION METHODS
}

\author{
Joanna ORYMOWSKA ${ }^{1}$ \\ Paulina SOBKOWICZ ${ }^{2}$
}

\begin{abstract}
This article presents the main hazards that occur in inland navigation and their impact on the vessel. Characteristics of the methods were used to identify threats. Examined such methods as: HAZOP, FTA, ETA, FMEA and SWIFT. There was shown the model identification of hazards on the example of steering gear damage of inland vessel moving on the straight fairway.
\end{abstract}

PODSUMOWANIE: W artykule przedstawiono główne zagrożenia występujące w żegludze śródlądowej i ich wpływ na statek. Charakterystyka metod została wykorzystana do identyfikacji zagrożeń. Zbadano takie metody jak: HAZOP, FTA, ETA, FMEA i SWIFT. Przedstawiono model identyfikacji zagrożeń na przykładzie uszkodzenia statku sterowego poruszającego się po prostym torze wodnym.

KEYWORDS: Hazards identification, Inland shipping, HAZOP, FTA, ETA, FMEA, SWIFT, Risk analysis.

SŁoWA KLUCZOWE: Identyfikacja zagrożeń, Żegluga śródlądowa, HAZOP, FTA, ETA, FMEA, SWIFT, Analiza ryzyka.

\section{Introduction}

Inland waterway transport is considered as one of the safer and cheaper modes of transport. Still, the operation of inland units associated with a risk of e.g. damage of the cargo and the ship, the threat of human life and environment pollution. Hazard identification is the first step in the formal safety assessment. Its purpose is to identify all the factors, which may affect the operational safety of the vessel. The proper term of threats allows for development of appropriate procedures, aimed at the elimination of the threats source.

\section{Inland waterways hazards}

Risks occurring in inland transport can be classified due to the factors that cause them. These are: Hazards arising from the transport of cargo; Hazards arising from human error; Hazards arising from failure of navigation devices/steering/other; Hazards arising from area specifics.

\footnotetext{
${ }^{1}$ Maritime University of Szczecin, Waly Chrobrego 1-2 Street, 70 - 500 Szczecin, Poland. E-mail: j.orymowska@am.szczecin.pl.

${ }^{2}$ Maritime University of Szczecin, Waly Chrobrego 1-2 Street, 70 - 500 Szczecin, Poland. E-mail: p.sobkowicz@am.szczecin.pl.
} 


\subsection{Hazards arising from the transport of cargo}

Inland shipping is a type of transport, which deals with the carriage of all kinds of cargo, including oversized cargo and containers. In case of river units, especially sea

- river vessels, important is to load the vessel correct. Uneven distribution of load in the cargo spaces or on deck can lead to heel or trim. Too much trimming, especially at higher speeds results in an increase in subsidence of the vessel. This phenomenon is particularly dangerous on the waters of the small depths, where the under keel clearance is small. The lack of monitoring and control of the value of the current draught and its relation to the depth can lead to grounding. In case of carriage of containers, their subsequent layers increase the supply surface, which on the open waters and with a strong wind can make it difficult to maneuver. A special type of cargo is dangerous goods, the carriage of which is associated with risks such as explosion. It is necessary to their proper distribution and keep appropriate conditions during transport [5].

\subsection{Hazards arising from human error}

A major factor of accidents cause on inland areas is human error. Shipping is commonly applied rule $80: 20$, which says that $80 \%$ of the accidents was humancaused, while $20 \%$ for reasons were independent of him. Regardless of whether this is intentional or unintentional, can lead to an accident. Fig. 1 shows the classification of human errors [4].

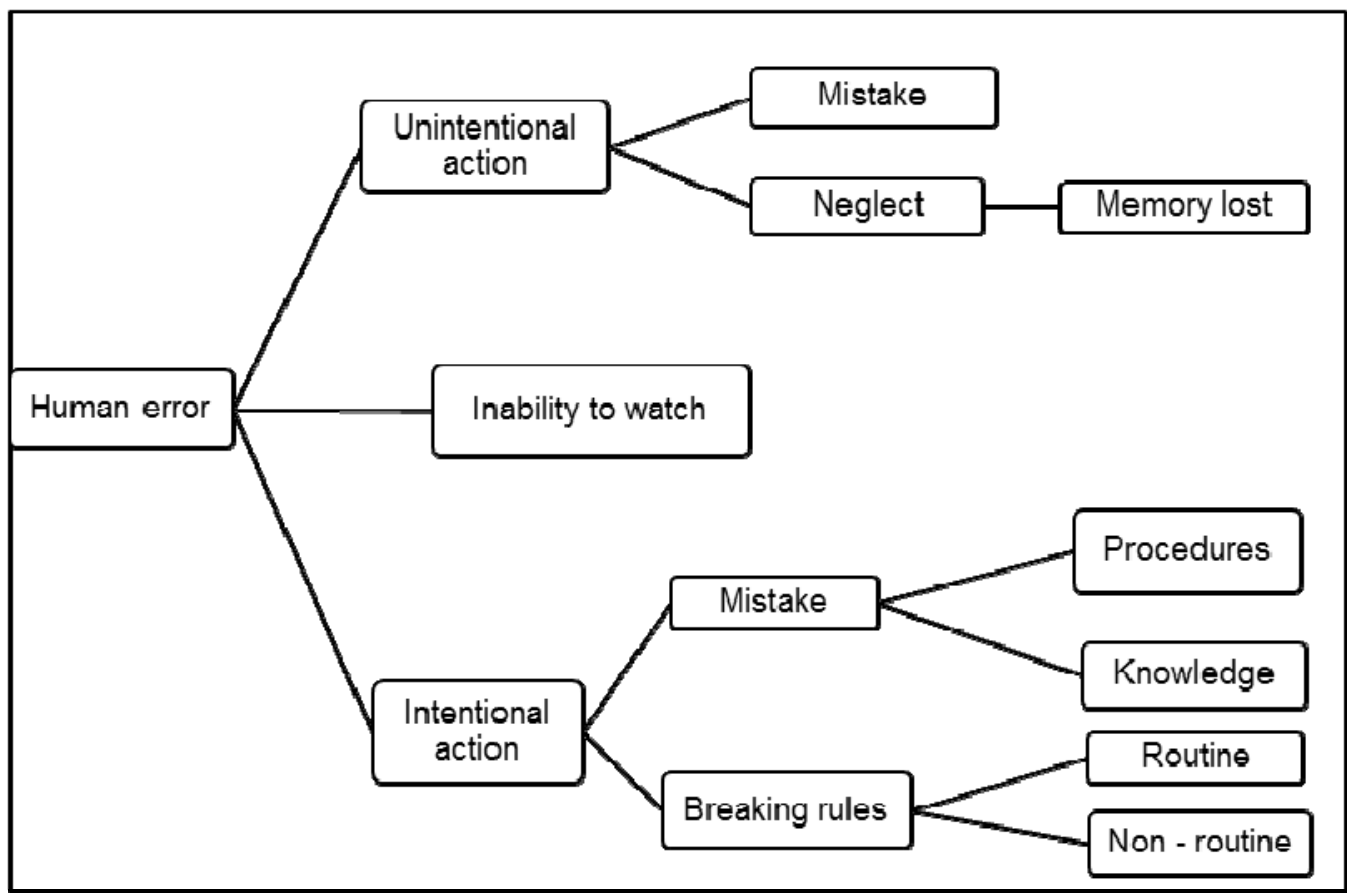

Fig. 1 Classification of human errors [4]

If the descent of unit from the axis of the fairway is observed early enough and the person on the bridge will behave in accordance with the procedures (will be back on the right course), the event will not generate any losses. Due to the lack of reaction to the descent of unit from the axis of the fairway, may be collision with another unit (moored or passing the lane). The lack of a suitable response to the descent of unit 
from fairway axis may result in: collision with another vessel especially while overtaking or passing; collision with another - moored vessel; collision with jetty; collision with fixed object; grounding.

The consequence of each event are different and depend on many factors including the speed of the ship, the kinetic energy of a collision or impact and the place of contact with the bottom. In case of collision/crash/grounding, are associated also loses caused by demurrage, towing or necessary repairs.

\subsection{Hazards arising from failure of navigation devices/steering/other}

Each of the navigation or steering equipment is characterized by the intensity of damage. This means that, within a specified time period (hours, years) may crash. To determine the reliability of the technical support unit, it would be necessary to determine the reliability of each of its components. In the case of a ship is a problem so complex, that construction of the models bases on the main devices such as radar, main engine, aggregates, or generators. To determine the intensity of damage to individual devices, must be specified the number of failures within a fixed period of time [5]. The intensity is dependent on the use of data elements e.g. in case of the ruder, its moves are important, and on the engine will affect the hydrometeorology conditions.

\subsection{Hazards arising from specifics area}

By the characteristics of the analyzed area it is possible to identify such risks as: grounding, restrictions in the vertical plane, too small clearances under bridges and conformation of a navigation route. Knowledge about navigation hazards and allows to avoid risks. From the safety point of view, important are information about visibility, currents and winds. Additional elements to be taken into consideration is the presence of RIS as well and the movement of the other vessels [5].

\section{The methods used to identify the hazards}

Main ideology of hazard identification is to identify all possible strings of events leading up to the event life-threatening the safety of the unit. Early detection and determination of the dangers enables effective prevention in the article shows the characteristics of the methods commonly used to identify threats. These are the methods: HAZOP, FTA, ETA, FMEA and SWIFT.

\subsection{The technique of HAZOP (Hazard and Operability studies)}

One of the commonly used analytical methods, otherwise known as the technique of key words. Is intended to indicate deviation from the acceptable levels on the basis of the indications of the type: too high, too low, too little, too much, etc. Used mainly to determine the ship's systems. Analysis is performed using this method carry out experts (engineers, technologists, designers, experts of the control and test facilities - measuring) under the leadership of the leader [1, 2, 3]. In table 1 is an example set of words used in the hazard identification based on HAZOP technique. 
Tab. 1 Examples of sets of words used in the hazard identification based on HAZOP technique [7].

\begin{tabular}{|c|}
\hline NO or NOT \\
\hline MORE \\
\hline LESS \\
\hline PART OF \\
\hline OTHER THAN \\
\hline EARLY \\
\hline LATE \\
\hline BEFORE \\
\hline AFTER \\
\hline
\end{tabular}

HAZOP technique can be applied to each stage of the construction or operation of the technology [7]. Generates a mainly qualitative results. HAZOP technology is based on a systematic review of design intent and the technological process for deviations from the accepted parameters. It is used mainly to determine possible incidents that may endanger the health and human life, the environment, cause damage to the equipment and technological problems. Fig. 2 shows the main steps of the proceedings when you use methods of HAZOP.

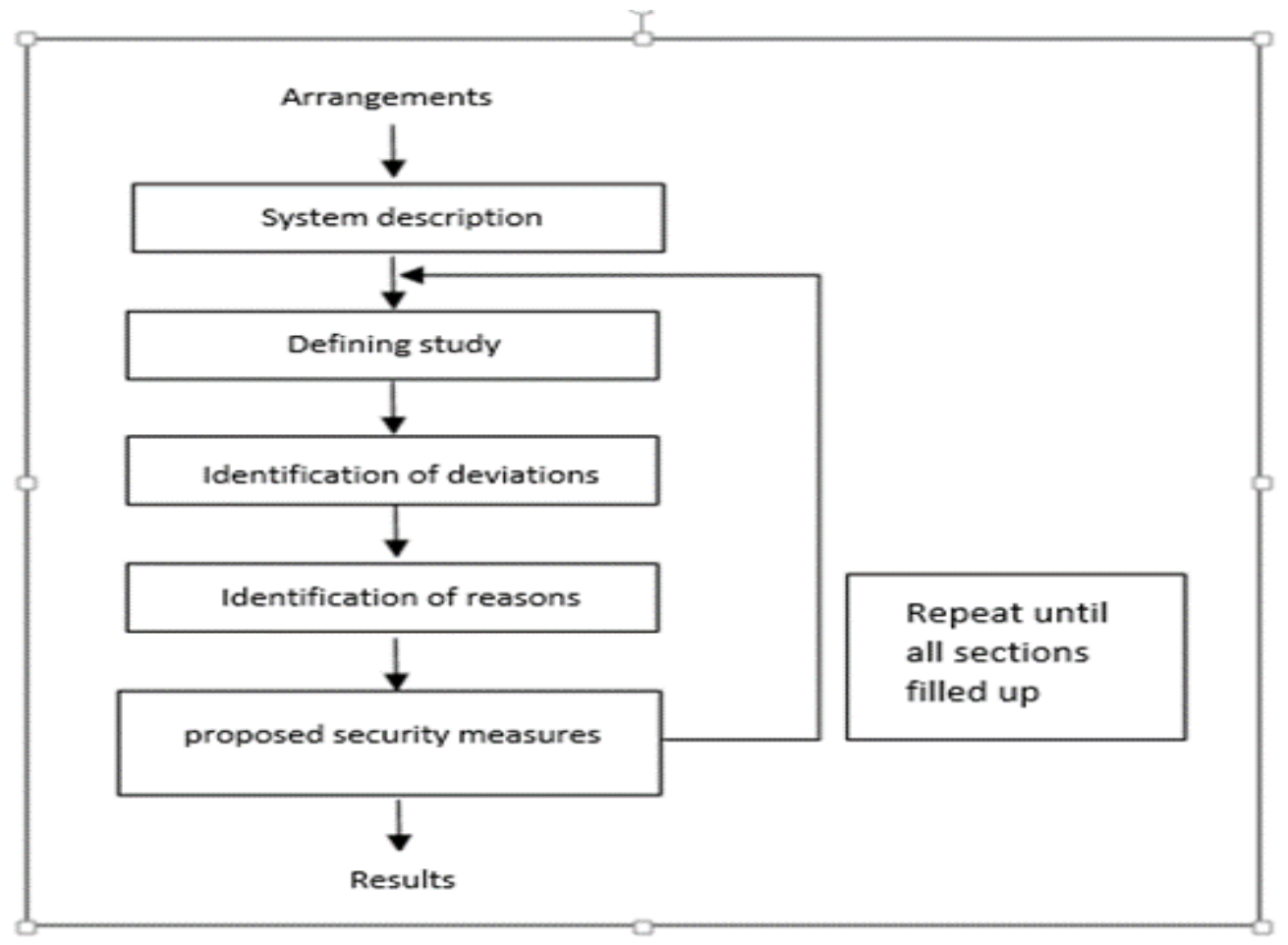

Fig. 2. The main stages in the HAZOP procedure [2] 
A form used when working using the technique of HAZOP consists of the following elements [1,3]: the word guiding is identifying potential deviations from design intent; variation - changes in properly operating system; cause - real causes of these deviations set during "brainstorm" effects - the consequences of incorrect functioning of the system; security measures - measures to prevent deviation; recommendations -proposals to improve security.

Sample form for hazard identification by HAZOP method presents table 2 .

Tab. 1 Sample work sheet in the analysis, HAZOP [2]

\begin{tabular}{|l|l|l|l|l|l|l|l|l|}
\hline \multicolumn{2}{|c|}{ HAZOP } & $\begin{array}{l}\text { Project: } \\
\text { Object: } \\
\text { Page: Date: }\end{array}$ \\
\hline No & $\begin{array}{l}\text { Guidig } \\
\text { word }\end{array}$ & $\begin{array}{l}\text { Devia- } \\
\text { tions }\end{array}$ & No & Causes & No & Effects & $\begin{array}{l}\text { Safety } \\
\text { measures }\end{array}$ & $\begin{array}{l}\text { Recomm- } \\
\text { endations }\end{array}$ \\
\hline
\end{tabular}

3.2. The technique of FTA (Fault Tree Analysis) - the construction of incapacity / fault tree.

Model built using the techniques of FTA aims to identify the relationship between damage equipment on ships and errors arising as a result of human or external factors. The construction of fault tree starts from identification of the effects of the event and passes in the direction of the events of earlier (prior). Indicates the possible combinations of events that may lead to which is specified. Event tree is used for qualitative and quantitative analysis [2]. In the FTA are used in Boolean logic. The main steps in FTA: determine of the initial events; determine the events/indirect damage; construct of tree damage, using event binding logical gates; identify the fundamental event leading up to the main event; specify the probability of occurrence of the initial event; calculate of the probability of occurrence of the final event; analysis of the results along with the fixing of the dominant events; the sensit ivity analysis to check how change the probability of damage to one item from a set of influences on the likelihood of the occurrence of peak events.

The purpose of the method is to identify the cause of failure instance, the determination of the frequency of occurrence of dangerous states and identification of critical components of the system. The basic elements of the event trees (Fault Tree-FT) are gates and events [1, 2, 3]. Table 3 shows the gateway used for the analysis of the FTA. 
Tab. 2 List of the gates symbols used in the FTA [2]

\begin{tabular}{|c|c|c|}
\hline $\begin{array}{l}\text { Gate's } \\
\text { Symbol }\end{array}$ & Gate's name & Symbol meaning \\
\hline & AND & $\begin{array}{l}\text { The output event occurs, if all input events occur } \\
\text { simultaneously }\end{array}$ \\
\hline & OR & $\begin{array}{l}\text { The output event occurs, if it takes, although one event } \\
\text { input }\end{array}$ \\
\hline & Inhibit gate & Input output product is followed by a conditional event \\
\hline$\pi$ & $\begin{array}{l}\text { Priority AND } \\
\text { gate }\end{array}$ & $\begin{array}{c}\text { Precedence over the conjunction of events from left to } \\
\text { right }\end{array}$ \\
\hline$\pi$ & $\begin{array}{l}\text { Exclusive OR } \\
\text { gate }\end{array}$ & $\begin{array}{l}\text { The output event occurs, if followed by one (not more than } \\
\qquad \text { one) the input event }\end{array}$ \\
\hline
\end{tabular}

Hazards identification using FTA is used both in risk analysis and determination of reliability. Specifies the relationship between the peak events and the underlying events. Fault tree construction uses a gateways connecting the event using a logical relationship. Based on the fault tree can be determined exactly, what was committed errors which actions have not been watched, and what actions have been taken to prevent accident. 


\subsection{ETA technique (Event Tree Analysis) - building of event tree.}

ETA technology is based on the graphical model depicting the relationship of cause and effect - in the event. Hazards identification begins with determining the initialization event and consider all possible strings of events that are consequences of the initialization event. The probability of the effect is determined by multiplying by the probability of all the events. The technique of event tree analyses the way from beginner to final events taking into account partial events having a decisive impact on the status of the analysis process. In many cases, a single event can result in different consequences depending on the performance or failure of the items/systems/operator activities, to be master of this event. ETA is method used to build the object model of probability for risk analysis. There are two forms of this technique: before the accident and accident. The technique before the resultant was applicable to determine the events and the assessment of a likelihood of their occurrence. After accident technique was used to analyze the failure and identify the functional safety systems failures.

Analysis procedure ET consists of six major stages: identify the initiating event that can lead to a specific failure; identify safety features are applied to mitigate the effects of the initiating events; construct of the event tree; descript of the resulting from the construction of the tree sequence; specify the minimum cross-sections of the tree; develop of documentation.

Fig. 5 Presents the method to conduct the analysis of the data using the event tree.

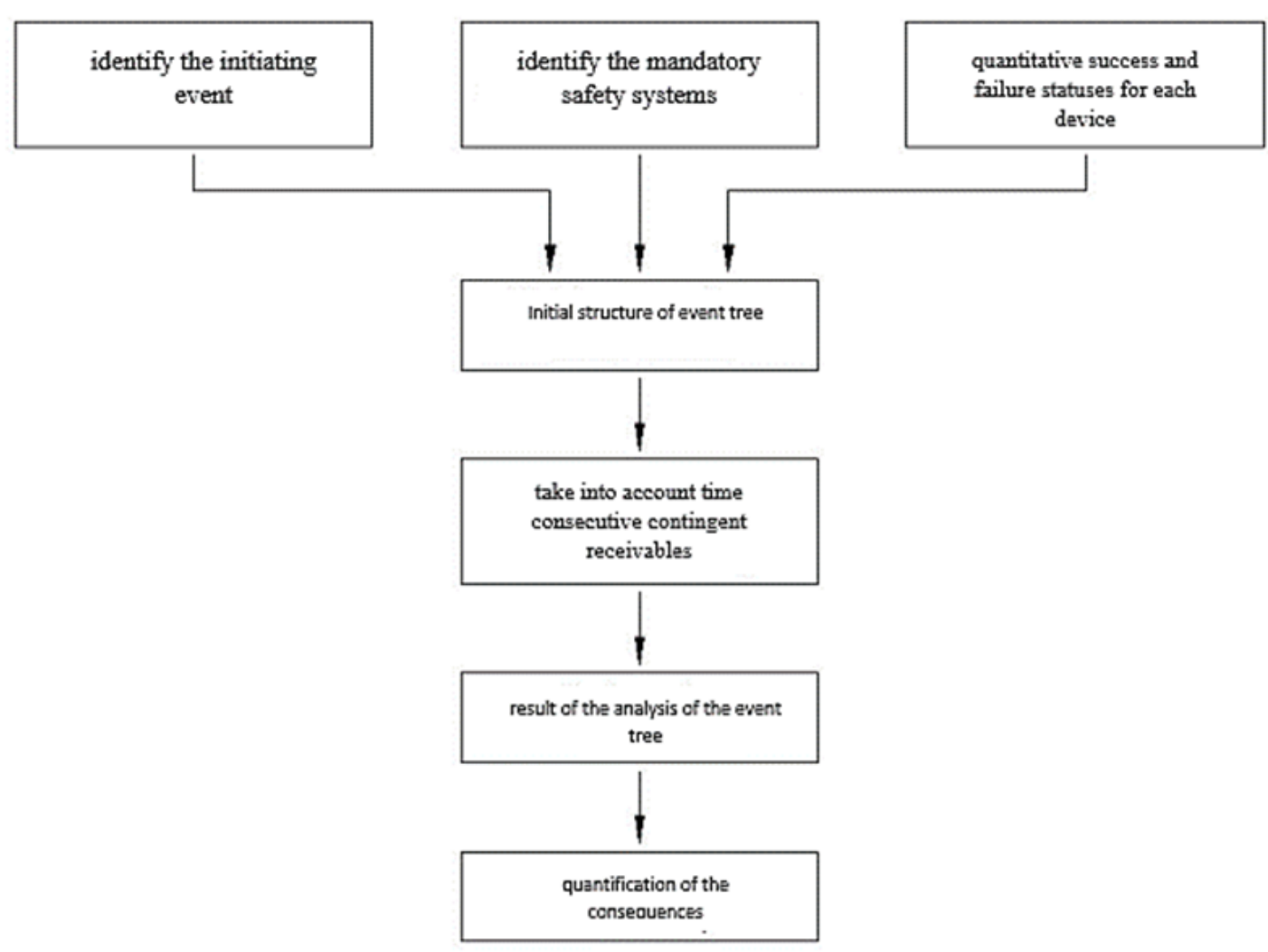

Fig. 2. Event tree analysis [2]. 
Each event has two branches that determine the success of the (positive) or lack of success of the (negative). The probability of events contains between 0 and 1 . The sum of the probabilities of the event and its lack of is equal to 1. Hence, if the entire event is described a collection of this success can be described as $P(A)$, while the failure as an event to the contrary: $1-\mathrm{P}(A)=\mathrm{P}(\bar{A})$.

3.4. The technique of FMEA (Failure Mode and Effect Analysis, the method of damage ways and effects analysis)

Is used to determine the damage, that have a significant impact on the operation of the entire system (mainly its efficiency). Evaluate the reliability of individual components of the system. Analysis of the types and effects of damage to the FMEA is look up table elements of the systems, equipment, their possible damage and effects on other components, systems or the state. The purpose of the FMEA is to identify specific shortcomings of the process and their exclusion or minimize their effects. This is achieved by determining the cause and effect relationships, depending on the potential creation process by defects - taking into account the risk factors. Thanks to this process is improved continuously through in-depth analyzing and introducing amendments which are aimed at eliminating the sources of defects and improve the performance of the product. Method is described to standard PNIEC 812 [4]. FMEA analysis was divided into two types: FMEA product - technology oriented to optimize the reliability of the product. On the basis of the assessment shall be made of strong and weak points of the product; FMEA process consists in determining factors of disorganizing production process. FMEA consists of five main steps: the characteristics of the system and its basic functions and the minimum requirements that determine its operation; identification of possible malfunctions and system failure; identification of the consequences of failure for each system failure; determination and evaluation of methods to detect system failure; description of the reduction and the Elimination of adverse effects.

Quantitative analysis of defects is used to describe the relation cause-defect-effect. Assessment of this relationship is determined on a scale of 1-10, divided into three categories: the risk of defects/causes - R; the ability to detect the emergence of causes before it cause any defects - W; the importance of disadvantages for the user - Z.

Based on the determination of these values shall be the number of priority, which takes a value between 1-1000, and along with its growth increases the risk of defects. The number of priorities is presented, using the formula:

$$
P=R \times W \times Z
$$

FMEA analysis documentation creates a look up table report describing the effects of damage to the equipment/system to other devices/components of the system. Table 4 shows the FMEA analysis documentation. 
Table 4 the FMEA method [6]

\begin{tabular}{|l|l|l|l|l|l|l|l|l|l|l|l|}
\hline \multicolumn{2}{|l|}{ System: } & \multicolumn{2}{l|}{ Drafted by: } \\
\hline \multicolumn{2}{|l|}{ Table no: } \\
\multicolumn{2}{|l|}{ Dystem } \\
description
\end{tabular}

\subsection{SWIFT technique (Structured What-If checklist technique)}

Technique of team „brainstorming”. Experts teams put questions and identify potential risks. The SWIFT method aims to: identify risks; determine the effects of the occurrence of each event; designate possible measures/methods of reducing risks.

SWIFT technique is divided into three stages: stage 1 - preparation - involves the analysis of the current situation, hearing with the applicable rules and procedures. Based on the stage 1 are specific questions that will try to answer team experts. stage 2 - review - presentation of the problem and putting the right questions to identify risks and develop remedial procedures. stage 3 - documentation - report from work with SWIFT technique. Determinate the hazards and their effects.

To document the work of using the SWIFT technique can be used sheet presented in table 5.

Tab. 3 Example of the SWIFT work sheet [3]

NAME

DATE

NO OF DOCUMENTATION

MEMBERS OF THE TEAM.

\begin{tabular}{|l|l|l|l|}
\hline WHAT - IF & CONSEQUENCES/HAZARD & REMEDIES & RECOMENDATIONS \\
\hline
\end{tabular}




\section{Hazard identyfication model on example of the steering gear damage}

The analyzed event was the inland vessel passing the straight fairway. During the passage of steering gear was damaged (initialization event). Threat independent of the human factor is the corruption of a navigation device and steering gear on the ship. Instantaneous threat with preserved control over the movement of the vessel causes loss only in the form of costs of repair/servicing equipment. Rudder damage can lead to loss of ship's control.

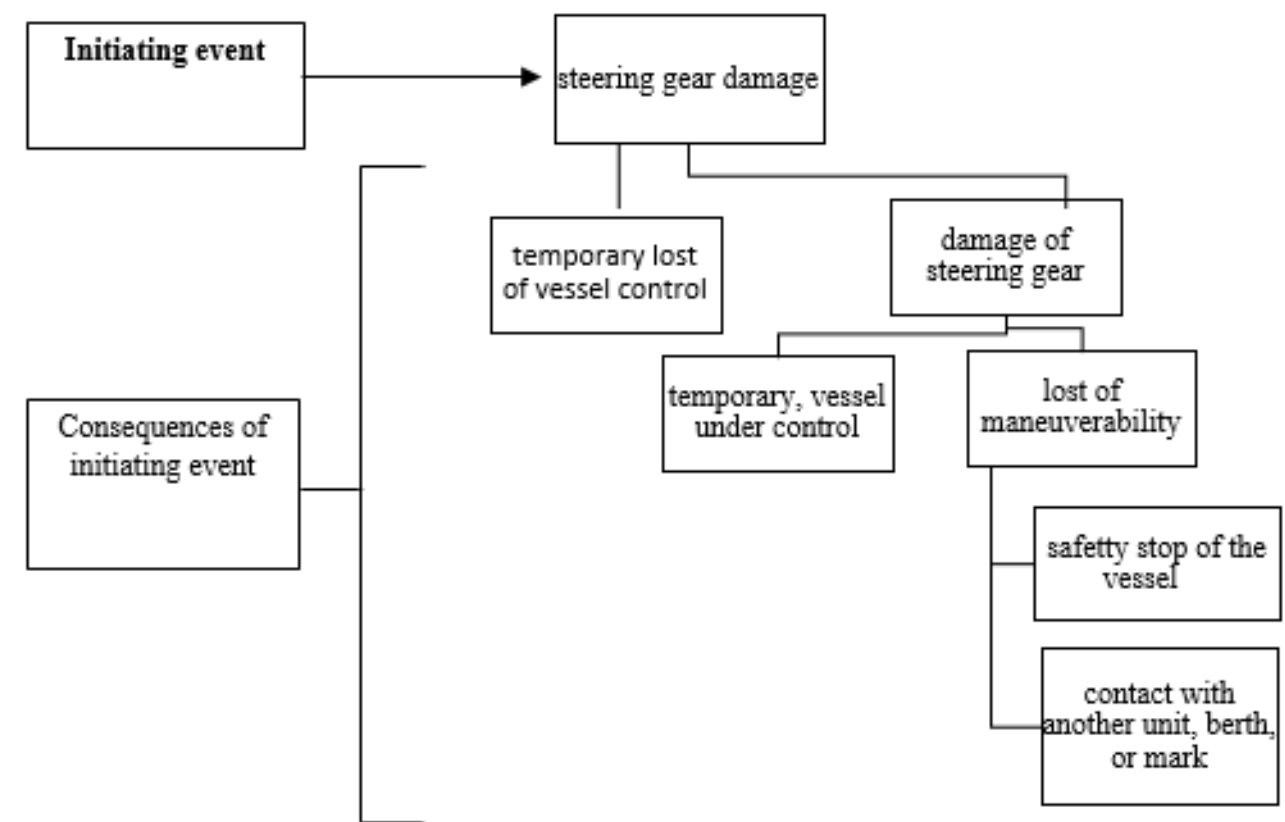

Fig. 3 Hazard identification model built using the ETA techniques Initiating event is damage of the steering gear. Table 5 shows the hazard identification model developed on the sheet used in the analysis of HAZOP.

4. 1. For deviation (the state to deviate from the proper operation of the unit) losing control on the ship. This may be caused by damage to the rudder, which can lead to the units of the axes of a navigation route or blackout. In the event of damage to the rudder applied security measures are frequent checks that my detect irregularities in the functioning of the steering gear. It's recommend also to check the rudder before the output units. Damage to the rudder during the transition units shipping route, endanger the safety and other users. As a result of the blackout, vessel may stop responding for his movement, which may lead to a collision of a ship with another unit/object/jetty. To prevent such situation, is recommend to install the sensors and alarms to monitor the energy facilities. Security measures are also frequent checks and a review of the devices. Table 7 shows the hazard identification model developed on the sheet used in the FMEA.

The analysis carried out by the FMEA is a method that allows for a precise description of the both test system, in where is a failure and damage effects. Considered damage is divided into components, which are analyzed separately for impact damage to the function of the system. 
Tab. 8 shows the hazards identification model developed on the sheet used in the analysis of the SWIFT.

SWIFT'S method is one of the simplest ways to identify risks, which is based on posing simple questions about risks. Sample sheet consists of four questions: What kind of threat occurs (What if)? What can be the effect? What measures should be taken? What recommendations can be applied?

Tab. 4 Example of the SWIFT work sheet.

\begin{tabular}{|c|c|c|c|}
\hline \multicolumn{4}{|l|}{ NAME. } \\
\hline \multicolumn{4}{|c|}{ NO OF DOKUMENTATION....................................... } \\
\hline \multicolumn{4}{|c|}{ TEAM MEMBERS $\ldots \ldots \ldots \ldots \ldots \ldots \ldots \ldots \ldots \ldots \ldots$} \\
\hline $\begin{array}{l}\text { WHAT } \\
- \text { IF }\end{array}$ & $\begin{array}{l}\text { CONSEQUENCES/HAZARD } \\
\text { S }\end{array}$ & REMEDIES & $\begin{array}{l}\text { RECOMMENDATION } \\
S\end{array}$ \\
\hline $\begin{array}{l}\text { Steerig } \\
\text { gear } \\
\text { damage } \\
\text { during } \\
\text { passage } \\
\text { on the } \\
\text { straight } \\
\text { fairway }\end{array}$ & $\begin{array}{l}\text { Descent from the axis of the fairway } \\
\text { /collision with the jetty/another } \\
\text { vessel/object }\end{array}$ & $\begin{array}{l}\text { Steering gear } \\
\text { controls/checklists }\end{array}$ & $\begin{array}{l}\text { Tests of the steering gear } \\
\text { before } \\
\text { departure/sensors/alarms }\end{array}$ \\
\hline
\end{tabular}

In this case, the threat is damage of steering gear. Effect was considered adescent units with the axis of the fairway which generates another threat in the form of the possibility of a collision with another unit, the jetty or the object. In order to ensure safety it is recommended that the introduction of checklists, controls of the steering gear and rudder before the departure. Additional indicators of threat are sensors and alarms. Their use allows for earlier detection of the problem and quick elimination.

\section{CONCLUSIONS}

Hazard identification is an important element of risk estimation procedure. Its main advantage is the ability to determine the problem and events that had an impact on his appearance. Commonly used method in the analysis of risks is HAZOP. This method is characterized by a thorough review of the assumptions of the entire technological process, which is designed to specify all possible deviations from the accepted standards. HAZOP work sheet takes into account deviations, their causes and effects, safety measures, and recommendations for use. SWIFT'S method is based on questions that have to define the problem and to find remedies. This is one of the more creative methods, because it is based on the so-called method of brainstorming. Like method HAZOP or FMEA, working with SWIFT methods shall be documented in the form of sheets, which in words describe defined risks. Methods such as ETA or FTA represent the identification of hazards in the way allowing to 
visualize the problem using the gates set out by using the appropriate symbols. Estimation of impact damage on the process allows to specify remedies and recommendations, which ensure safety and minimize the risk of hazards.

\section{REFERENCES}

Borysiewicz M., Furtek A., Potempski S., Poradnik metod oceny ryzyka związanego z niebezpiecznymi instalacjami procesowymi, 2000r. Otwock-Świerk.

Brandowski A. Metodyka Formalnej Oceny Bezpieczeństwa Żeglugi (FSA), 1998r. Gdańsk.

Brandowski A. Metodyka Formalnej Oceny Bezpieczeństwa Żeglugi (FSA), Publikacja Informacyjna NR 19/1, PRS, 2002r. Gdańsk.

Gucma L. Zarządzanie ryzykiem w rejonie mostów usytuowanych nad drogami wodnymi w aspekcie uderzenia jednostek pływających, 2013 r. Szczecin.

Gucma L. Modelowanie czynników ryzyka zderzenia jednostek pływających z konstrukcjami portowymi i pełnomorskimi, 2013 r. Szczecin.

Huber Z. Analiza FMEA procesu, 2007r.

Recibido el 20 de octubre de 2018. Aceptado el 31 de diciembre de 2018 